\section{MAJOR CHANGES AFFECTING EU FUNDED LOAN AND EOUITY SCHEME MANAGEMENT IN 2021-2027 BUDGETARY PERIOD}

Márk Batón

Approximately ten percent of support from the European Union structural funds sources was utilised as financial instruments in the 2014-2020 EU budgetary period. The term 'financial instruments' represents support in the form of loans and capital injections in Hungary. Programmes for 2021-2027 have not been finalised yet, but major amounts of money are expected to be used in the form of financial instruments. Therefore, one should review the changes affecting the criteria to use EU structural funds, which determine development policies in the next period regarding loan and equity schemes.

Both the EU and the Hungarian regulatory framework have been established, they can be studied and used as the starting point of further planning. In this paper the major components of the relevant regulatory framework including its practical conclusions to be expected are discussed.

\section{JEL codes: G28, F63}

Keywords: financial instruments, European Union, cohesion policy, preferential loans

\section{BASIC CONCEPTS OF THE COHESION POLICY}

\section{OF THE EUROPEAN UNION}

The basic concepts used in Cohesion Policy need to be reviewed before discussing financial instruments. European Cohesion Policy is implemented under shared management: the European Commission and Member States involved are jointly responsible for its implementation. Developments are funded based on comprehensive regional programmes termed operational programmes. Operational programmes are typically designed separately by Member States and the economic areas involved, like, for example, the Economic Development and Innovation Operational Programme of Hungary (EDIOP). Programme managers

1 Márk Bató PhD, Prime Minister's Office, National Coordination Agency of European Structural and Investment Funds. E-mail: mark.bato@me.gov.hu. design operational programmes to ensure the financed projects are organically linked and coordinated to promote the convergence of Member States and their regions.

Managing authorities are responsible for the implementation of operational programmes. Regarding the financial instruments applied, the managing authorities may execute loan and guarantee type forms of support at discretion. That is no possible for equity programmes due to the transfer of ownership rights, so financia intermediaries must be involved in the implementation of financial instruments. A managing authority that has gained experience in the field of non-repayable grants will often invite an organisation with experience in the field of financial instruments to participate in the implementation of all financial instruments. Typically, nationa development banks are selected for the purpose since they are skilled both in development and financing. A selected financial intermediary may involve further intermediaries in the implementation of financial instruments that will be charged with the actual disbursement of the funds to final recipient project owners. In that case, development policy capacities are not required, as those intermediaries distribute 'oven-ready' financial products to the target group identified.

Operational programmes are built along priority axes that break down differen areas of intervention into sub-areas. In the case of EDIOP referred to above, for instance, priorities include the development of small- and medium-size enterprises or supporting research and development. Specific objectives may also be set so that the progress achieved on a priority axis can be measured.

\section{APPLICATION OF FINANCIAL INSTRUMENTS}

\section{IN COHESION POLICY}

One should note for a start there are three reasons why financial instruments in addition to the classical form of non-repayable grants have been introduced into Cohesion Policy. Analysis of support provided to profit-making investments has shown repayable aid forms encourage more efficient operations. In that case, project owners manage the support as an investment rather than one-off income. The repayment obligation increases their interest in using the funds efficiently. Another argument for applying financial instruments is the funds so recovered can be used again. In addition to repayment, the so termed leverage effect can also increase available funds. In this case the leverage effect means additional investment by private investors since the $\mathrm{EU}$ investment has reduced risks to a level they can and are willing to accept.

The philosophy and the set-up of the structure of financial instruments differ from the approach used with non-repayable grants. In this case, the beneficiary 
is the financial institution that offers the supported financial product. As a result of the support, the financial institution issuing financial instruments will be able to fund economic actors it could not have funded otherwise due to the extreme risk involved. The financial institutions acting as intermediaries receive management fees in return. In the 2007-2013 EU budgetary period Hungary made use of approximately HUF 250 billion in the form of financial instruments. The amount increased to HUF 700 billion in the 2014-2020 EU budgetary period.

An important aspect for planning support in the form of financial instruments is the need to avoid that existing forms of financing are ousted from the money market. The aid must finance new projects that would not have access to funds otherwise. Therefore, the preparation of an ex-ante analysis must be the first step in planning financial instruments to identify gaps of funding in the market and to set the parametres of the product accordingly.

As a rule, an ex-ante analysis must include the following elements:

1) the funds made available including the estimated/planned amount of private investment generated because of leverage. The sum of the two represents the total amount of the estimated/planned support.

2) In addition, the form of support/funding, and the actual product description must also be specified. This should include the potential means of differentiated treatment of co-investors, which may become necessary to make them interested in providing contribution.

In addition to the budget and the product, the planned target groups must also be identified as well as the expected contribution of the financial instrument applied to the objectives of Cohesion Policy and to its indicators.

\section{CHANGES IN THE 2021-2027 PROGRAMMING PERIOD}

\subsection{Combined form of support}

The combination of financial instruments and non-repayable grants is a key element of the set of provisions in the programming period 2021-2027. The option did exist already in the 2014-2020 period and combined support was applied in Hungary, but due to the extremely complicated rules of implementation, the stakeholders did not regard that otherwise promising form of support a success.

There are, however, basic differences between the rules of implementation of combined aid in 2014-2020 and in 2021-2027. In the 2014-2020 period the EU did not allow a uniform set of rules to be applied for implementation; one had to observe the rules of financial instruments for the part of financial instruments while those relating to non-repayable grants were the standard in the case of non-repayable grants. This made the procedure extremely difficult for all parties involved and continuous discussions, often at project level, were needed between the financial institutions managing financial instruments and the managing authorities in charge of non-repayable grants.

One can mention, for example, the provisions regarding the commencement of an investment project, which resulted in several misunderstandings during implementation in Hungary. The provisions for financial instruments specified a project could not have been completed before the relevant funding decision was made. On the other hand, the deadline for non-repayable grants was the submission of a funding request and that was the date before which the project could not have been completed. Those provisions caused major problems in the case of combined forms of support where the main objective is to drive target groups towards recoverable forms of support. Members of the target group had been mostly using non-repayable grants earlier so they planned their projects according to the implementation procedure learnt there in the belief they could complete them after submitting their funding requests. However, the decision process in the case of combined aid was extremely long, mainly at the beginning, due to the time required for the exchange of information between the different implementing bodies. Because of this, project implementation was often delayed, and the risk arose that project owners could not make use of combined aid including financial instruments as the closing of the project preceded the relevant decision.

A proposal the parties involved in implementation have submitted, which has now been accepted, can considerably improve the situation. Accordingly, all the combined support can be provided under the provisions relating to financial instruments if it also includes supplementary non-repayable grant. To avoid abuse, it is only possible if the amount of non-repayable grant is not higher than that of the financial instrument. Another condition to be fulfilled is that both forms of support must be provided by the body implementing the financial instrument This new implementation option is expected to have a promising future. It can be suitable for effective operation matching the needs of applicants if the new set of rules is accompanied with a proper and mature practice of implementation.

\subsection{Selection of financial intermediarie}

In addition to the above form of combined support in one operation, a reform of the rules on how to select the implementing bodies of financial instruments is of major importance. Regulatory problems were clearly perceived in Hungary 
in the 2014-2020 programming period, which was one of the reasons why the actual commencement of programmes was sometimes delayed by as much as two years. During the 2014-2020 programming period the regulations were modified allowing national promotional banks to be directly selected to implement financial instrument programmes so that the managing authority did not need to announce public procurement tenders. No specific provision was included regarding the selection of financial intermediaries, so there the general rules of public procurement remained in effect.

The earlier regulations have remained practically unchanged for the 2021-2027 period. Accordingly, national promotional banks can be directly selected while no special rules apply to the selection of financial intermediaries. It does not mean that public procurement procedures are mandatory for selection, however, the general rules of public procurement shall be considered when deciding on the procedure to be used.

\subsection{Management costs and fees}

The provisions for calculating management fees, however, have been significantly modified. In the 2014-2020 programming period, detailed provisions applied to the calculation and payment of management fees. It was correspondent to the objective that the provisions regarding management fees should drive the performance of financial intermediaries. On the other hand, detailed provisions complicated the calculation and planning of management fees, thus generating high administrative burden for the parties involved. In line with experience, the provisions for the new programming period rely much more on stakeholders involved to agree on management fees. Remuneration based on performance continues to be the basic principle, however, it is not accompanied by specific numerical limitations. The earlier basic and performance related limits of remuneration broken down annually have been cancelled; there is a comprehensive limitation relating to the whole financial instrument, which is $7 \%$ of the financial instrument paid to project owners in the case of credit and guarantee schemes.

\subsection{On-the-spot verification}

New provisions have been introduced regarding the management verification of development programmes. Misunderstandings occurred during the implementation of earlier programmes as to the scope of management verification by the managing authorities. The provisions regarding the 2021-2027 programmes are unambiguous: on-the-spot verifications of final recipients need not to be conducted in the case of financial instruments; on-the-spot verification of the relevant financial intermediaries is sufficient.

\subsection{EU financing}

A new solution has been offered regarding EU financing of financial instruments Traditional ex-post financing has been changed because the liquidity of financial intermediaries must be ensured for their operation, so a specific part of the funds dedicated to the purpose of financial instruments can be drawn down ex-ante from the European Union. This was exercised via so termed phased contribution in the 2014-2020 programming period. In that way, $25 \%$ of the funds could be requested ex-ante after the programmes had been designed and financing agreements had been concluded with financial intermediaries. That provided the intermediaries with liquidity to launch the programmes. When $60 \%$ of those funds had been disbursed, another $25 \%$ could be drawn down to ensure uninterrupted liquidity.

There had been earlier experience regarding options for ex-ante payment of the whole funding amount, but it had not been satisfactory. It could occur that funding had been requested and then it was parked with financial intermediaries without actually using them for development purposes. It was a favourable shortterm solution for Member States since the funds had been paid from the EU budget and helped to meet strict criteria of disbursement targets.

To understand the unique part played by disbursement targets in EU Cohesion Policy, one needs to understand the related system of payments. The provision requiring automatic decommitments had been introduced to ensure the planning and scheduled implementation of the EU budget. The seven-year budgetary cycles make EU funding from the Structural Funds available to the Member States in annual breakdown. Payment of the annual amounts can be made in three consecutive years following the given year (' $n+3$ ' rule), however, if no disbursement is made within that period, the Member State loses the funds, the EU commitment is withdrawn.

The provision regarding the automatic decommitment provided an incentive for Member States to disburse funds as soon as possible. Using financial instruments was an ideal option, since even ex-ante payment was possible, which allowed for quick spending. The system of non-repayable grants is typically ex-post, allowing requests for payments to be submitted only after a project is implemented, which can delay the drawdown of EU funds significantly.

Although Member States were winners at the beginning, they could easily become losers later, since - to close programmes - they had to present how the financial instruments had been disbursed. It became known in several cases at that point funds had been parking with the financial intermediaries and no actua 
disbursement had been made. As a result, the phased contributions referred to above have been introduced, i.e., financial intermediaries received the total funds in $25 \%$ tranches matching the dynamics of disbursements made to project owners. Based on the experience of the 2014-2020 programming period, the payment system required further reform. Implementation issues arose when more than one financial intermediary had to be financed in parallel. It happened that some intermediaries who had been performing well were already close to disbursement of the first phase (25\%), but the Member State involved could not draw down further funds because the average had not reached the required limit as other intermediaries had performed poorly. In that way, the scheme penalised good performers, since it could not provide them with liquidity until the other intermediaries caught up.

The reform intends to solve the problem by continuing to provide ex-ante payment with a $30 \%$ limit. After that, however, no disbursement level is required to be reached for the next drawdown, instead, Member States can draw down funds ex-post. The first phase becomes a kind of advance payment that must be cleared - disbursed to project owners - till the end of the programming period. In that way the modified regime can guarantee liquidity for financial intermediaries via the $30 \%$ advance payment, at the same time it prevents unjustified parking of the funds with them.

The specific ex-ante EU funding resulted in the introduction of other supplementary provisions, including the provisions governing active treasury management. Because of advance payments, funds will be held by financial institutions for a certain time before being transferred to the target group. Observing the basic principles of fund management, or more specifically the principle of sound financial management relating to the EU budget, those funds must be managed until used and the income thus generated must be channelled back into the operational programme. Interest and other income generated must be used in accord with the objectives of the initial resources, they must be managed matching them in each and every respect.

\subsection{Role of centrally managed EU financial instruments}

In addition to the reforms affecting implementation, a conceptional change in the application of financial instruments funded from the EU Structural Funds can be observed as well. In the 2014-2020 programming period the European Commission exercised some pressure to drive Member States to make use of financial instruments rather than the traditional form of non-repayable grants.
The intentions of the Commission have changed for 2021-2027, centrally managed instruments are prioritised instead of quantitative growth.

The programme InvestEU covers the financial instruments of the European Union implemented directly; they are not managed jointly with the Member States, unlike Structural Funds programmes. For the most part, the objectives of the programmes reflect the development goals applied for the Structural Funds (SME development, supporting innovation, energy, and infrastructure development), but high-volume programmes are planned to be launched at EU level. The Commission's main argument to support the application of those instruments is the lower rate of expenses, so that the programmes can operate more effectively than individual ones operated from the funds of the Member States only. In the programming period 2021-2027, national promotional banks side by side with the European Investment Bank, may participate in the distribution of the central funds for the first time, which is expected to significantly contribute to strengthening the part played by InvestEU funds. Now the banks and other institutions planning to take part in implementation can be involved in financing the relevant programmes through national promotional banks as well as the European Investment Bank.

The Commission encourages Member States to contribute to the programmes already in operation rather than establishing separate programmes provided they can cover their development goals with InvestEU programmes. Funds from the Cohesion Policy allocated to Member States will continue to be used in the respective Member States only. It is still possible to design own programmes. In such cases project owners and financial intermediaries must be prepared for the parallel operation of programmes using central EU funds and specific ones using the funds of the Member States.

\section{FUNDING AGREEMENTS}

Funding agreements may be the most crucial point of reference for financial intermediaries for the implementation of EU funded financial instruments. Funding agreements governing the framework rules for financial intermediaries shall be concluded between the holding fund manager and financial intermediaries. Funding agreements shall include a description of financial products, the target group and potential combination with non-repayable grants. They shall also include a business plan of implementation, which also details the expected leverage effect. The expected outcome of the implementation of the financial instrument is another mandatory element of the agreement. Here, outcome means the evolution of the indicators reflecting the contribution to the specific goals 
of the priority. Provisions relating to monitoring and reporting are also part of funding agreements. Reporting shall cover the eligible amounts disbursed from the financial instrument, the eligible expenditure used for management costs and fees, the amount allocated to the financial instrument separating supplementary private and public contribution (leverage effect), the interests and other income generated from the financial instrument and reflows. Linked to audit activities, funding agreements must specify the documentation required. Documents relating to the EU Structural Funds must be retained for five years

Funding agreements, moreover, must regulate the specific way of fund transfer for the purpose of financial instruments and the necessity to indicate a need for funds by financial intermediaries in advance. Detailed provisions must govern active treasury management. The agreements must also cover the methodology of calculating management expenses and fees. The management of reflows and linked to it, the management of exit must be governed. Agreements must also include provisions on the potential withdrawal of funds. And finally, communication obligations of final recipients must also be included in the agreements.

The presence of provisions regarding the content of funding agreements is not a novelty compared to earlier rules of implementation, however, their content has been updated to match the new rules of implementation.

\section{SUMMARY}

To sum up, here are the areas of changes where financial intermediaries that intend to take part in the implementation of financial instruments funded from EU Cohesion Policy in 2021-2027 must be prepared for.

- A simplified so termed single-operation combined form of support (loan + non-repayable grant) can be applied.

- Financial intermediaries can also issue non-repayable grants in future, so the administrative burden because of the need to negotiate details with the managing authority is expected to be significantly reduced.

- The calculation of management costs and fees will be much simplified, which is expected to result in better transparency and predictability on the level of financial intermediaries.

- On-the-spot verifications of supported project owners is no longer an obligation for the managing authority, so financial intermediaries can carry them out on their own.

- The methodology of drawing down funds has also been modified to match market needs, so intermediaries can receive ex-ante funding to ensure liquidity, then they can use ex-post funding for their disbursements, and they must clear the advance by the end of the programming period.

As another major issue, the central EU funded financial instruments are expected to gain momentum and spread (according to the intentions of the European Commission).

We can provide a more detailed description of the financial instruments to be launched in Hungary when the operational programmes have been accepted. They are in the process of design and negotiations with the Commission are in progress. However, their content will not affect the rules of implementation, which have already been adopted. Potential financial intermediaries can use them as given during their preparations even before the actual content of specific financial instruments becomes known. 


\section{REFERENCES}

- Regulation (EU) 2021/1060 of the European Parliament and of the Council laying down common provisions on the European Regional Development Fund, the European Social Fund Plus, the Cohesion Fund, the Just Transition Fund and the European Maritime, Fisheries and Aquaculture Fund and financial rules for those and for the Asylum, Migration and Integration Fund, the Internal Security Fund and the Instrument for Financial Support for Border Management and Visa Policy. 24 June 2021.

- Commission Delegated Regulation (EU) No 480/2014 supplementing Regulation (EU) No 1303/2013 of the European Parliament and of the Council laying down common provisions on the European Regional Development Fund, the European Social Fund, the Cohesion Fund, the European Agricultural Fund for Rural Development and the European Maritime and Fisheries Fund and laying down general provisions on the European Regional Development Fund, the European Social Fund, the Cohesion Fund and the European Maritime and Fisheries Fund. 3 March 2014.

- Regulation (EU) No 1303/2013 of the European Parliament and of the Council laying down common provisions on the European Regional Development Fund, the European Social Fund, the Cohesion Fund, the European Agricultural Fund for Rural Development and the European Maritime and Fisheries Fund and laying down general provisions on the European Regional Development Fund, the European Social Fund, the Cohesion Fund and the European Maritime and Fisheries Fund and repealing Council Regulation (EC) No 1083/2006. 17 December 2013. 